\title{
Technoscapes and mediascapes influence on village and city relations in Manggarai, East Nusa Tenggara
}

\author{
Ans Prawati Yuliantari ${ }^{*}$ \\ ${ }^{1}$ Department of Indonesian Language and Literature Education, Universitas Katolik Indonesia Santu Paulus \\ Ruteng, Indonesia
}

${ }^{*}$ Corresponding author

E-mail address: tia.yuliantari@gmail.com

DOI: https://doi.org/10.21107/sml.v3i1.7112

\begin{tabular}{|c|c|}
\hline Article Info & A bstract \\
\hline $\begin{array}{l}\text { Keywords: } \\
\text { Technoscapes } \\
\text { Mediascapes } \\
\text { Ruteng } \\
\text { City } \\
\text { Village }\end{array}$ & $\begin{array}{l}\text { The development of infrastructure and information technology has a } \\
\text { significant impact on the relationship between Ruteng, the capital of the } \\
\text { Manggarai district, and the surrounding villages. The mobility of the people } \\
\text { between the cities and villages has led to new problems which previously did } \\
\text { not have a significant influence. The shrinking of the rural agricultural sector } \\
\text { and the development of the informal sector in the city are indicative of the } \\
\text { dynamic relationship between the two. In order to see the phenomenon of } \\
\text { changes that occur in the relationship between Ruteng and the surrounding } \\
\text { villages, a theory of landscapes by Arjun Appadurai is used. Interviews } \\
\text { were conducted with two entrepreneurs who employed people from five } \\
\text { villages, namely Wae Belang, Pong Murung, Purang, Lando, and Nanu, and } \\
\text { ten workers from those villages. Observations and literature reviews were } \\
\text { carried out to support and complement the data obtained by the interview } \\
\text { method. Technoscape, in the form of physical infrastructure development in } \\
\text { rural areas and mediascape in the form of television and radio shows, as well } \\
\text { as social media, became a pull factor for migration to Ruteng. Meanwhile, } \\
\text { the traditional view in the form of go'et (traditional expressions) and the } \\
\text { similarity of culture become the push factors for urbanization to Ruteng. }\end{array}$ \\
\hline
\end{tabular}

Citation suggestion:

Yuliantari, A. P. (2020). Technoscapes and mediascapes influence on village and city relations in Manggarai, East Nusa Tenggara. Simulacra, 3(1), 1-13. https://doi.org/10.21107/sml.v3i1.7112

Received 18 April 2020; Received in revised form 18 May 2020; Accepted 2 June 2020; Published online 25 June 2020. 


\section{Introduction}

Popular culture is often a means to display the reality of a community, including people's perceptions of the relationship between their native land and places outside their territory. This is evident in local rap songs that are quite popular among young people of Manggarai. One of the songs that show the relationship between overseas and regional origin is "Aku Retang Bao," (I just cried) a remake of a regional song, that famous in west part of Flores island, performed by Dodi RBC, a rapper from coastal area of Reo in northern part of Manggarai. In the first stanza, there are lines that state:

Nia lako nitu ka'eng,

(Where we are, that's where we live)

hitu tana mbate Manggarai

(That's Manggarai land)

hitu ngasang one nai

(In our heart)

Mai ga cama laing

(Let's get together)

dere landing nuk ase ka'e lembu nai,

(Singing because we miss comforting

relatives)

Sina tana caro laing,

(Far away)

Ruteng lodok Manggarai

(Ruteng is the center of Manggarai)

Based on the entire contents of the text, this song talks about the Manggarai people who migrate to the outside of the area in search of a better livelihood. Nevertheless, they always regard Manggarai as the center of their lives, both geographically and culturally. Manggarai, in this context, is lodok, which is the most crucial area where every Manggarai person returns from his wandering.

"Lodok" is the center or the cornerstone for the distribution of paddy or garden land in Manggarai in the form of a spider's web
(Janggur, 2010). It is from the lodges that the fingers or cicing are drawn towards the outer portion of the circle. Lodok can also be interpreted as the center of power or the center of government in a particular region. In this case, the song by Dodi RBC accurately describes the position of Ruteng as lodok of Manggarai. In his position as lodok, Ruteng has a superior position over the surrounding villages. Ruteng became an attraction for villagers to come and settle down on economic, social, and political grounds. The attraction is more significant with the advancements that have taken place in the region in decades.

Changes in relations between Ruteng as the city became the center of government, and the surrounding villages began to appear during the 1980s. This change occurred due to the central government program through REPELITA IV in 1984-1989, which encouraged infrastructure development in the form of roads and electricity connections in the Manggarai area (Webb, 1994). The emergence of roads and electricity connections to villages in various subdistricts, besides the Langke Rembong subdistrict as the center of the city, smoothed the mobility of residents who were previously constrained by topographical factors. Traveling along the hills that separate the Ruteng region from surrounding villages requires more than a day's walk, unlike vehicles that can cover that distance in a few hours. Meanwhile, electricity networks that were built to remote areas encourage more extensive access to information through radio and television broadcasts.

The entry of information from outside directly into the villages had a significant impact on the community, especially information about other areas that were previously only obtained from people who had traveled outside their area. Easy access to information changes the mindset and behavior of peoplein rural areas. The concepts 
of the relationship and interactions between their homes and outside areas differed. J.A.J Verheijen, a Dutch missionary priest in Manggarai and ethnographer (Willemsen, 1998), had seen this phenomenon since the 1950s when Manggarai people began to change their habits to adapt to the progress of the times (Hagul \& Lana, 1989).

The research question raised in this article is what determinants encourage Manggarai migrants? Moreover, why is Ruteng the choice for rural residents in Manggarai to live permanently or temporarily? Through the analysis, it is known that there are fundamental changes in relation concept of the village, where the majority of the population lives, and the city as the center of government, economy, and education. The change has an impact on the mobility of rural communities to Ruteng permanently or temporarily. This mobility occurs because of the change in the way of the population, which initially placed the village as the center of agriculture-based social and economic life into urban life that relied on the service and trade sectors. As a result, people change their orientation of livelihood systems from the agrarian sector to the trade and services sector. Changes in the orientation of the field of work not only encourage massive urbanization to the city but also cause a shrinking number of workers in agriculture and plantations that have been a mainstay in the countryside.

\section{Method}

In order to see the importance of the influence of infrastructure and information technology in framing the relationship between Ruteng and the surrounding villages, the concept of landscapes proposed by Appadurai (1996), namely technoscapes and mediascapes are used as a driver of interaction between cities and villages. Technoscapes, in this context, is the power of technology that drives cultural interaction and exchange with unlimited speed. Mediascapes, in the form of radio and television, forms a public opinion about villages and cities to create an "imaginary world" for rural and urban residents about the areas outside their homes. This mediascapes influences the mobility of villagers to Ruteng and Ruteng population's perspective on the village and the activities of its citizens.

This article is the result of qualitative research, in which the researcher makes an interpretation of something that is seen, heard, and understood (Creswell, 2016). Data obtained by interview, observation and literature review. Observations were made in Langke Rembong Subdistrict as an urban area and Ruteng Subdistrict as a rural area with residents working in the service sector and trading to the city. Interviews are conducted using the unstructured interview method, where the interviewer asks questions about the same thing to each informant, although the question's model can vary according to the situation and conditions at the interview (Dana, Dawesy, \& Peterson, 2013).

Theselectedinformantsareentrepreneurs who employ a minimum of residents from five villages. This selection based on the assumption, there is a difference between the pattern of labor-employer relations as a product of modern culture and the mindset and work of employees as a product of the culture of Manggarai that causes differences in viewpoints. Based on these criteria, a bakery owner and a vehicle spare-parts shop owner were chosen. Interviews were also conducted with ten workers from the two employers, who came from the villages of Wae Belang, Pong Murung, Purang, Lando, and Nanu. Interviews with non-permanent urbanists were conducted with three traders selling vegetables, cakes, and fuel. These three people were chosen because the majority of seasonal migrants in Ruteng are 
traders of the three types of merchandise. A literature reviews is used to support the observations and interviews conducted on selected objects.

\section{Results and Discussion}

The relationship between the city and the village, in the perspectives of most people, is placed as two opposing poles (Stewart Jr., 1958; Stead, 2002). According to Woods (2011), rural areas have always identified with traditional things, lack of public facilities and infrastructure, limited employment, close kinship, the agricultural sector as the main livelihood, and underdevelopment. It is inversely proportional to modern urban society, the availability of facilities and infrastructure for the public, industry, and trade as an economic source, and a large number of jobs. This opinion is appropriate to see the phenomenon of the relationship between Ruteng and the surrounding villages because, in reality, the rural areas in Manggarai lack public facilities and infrastructure and depend on the agricultural sector. While Ruteng, as the center of government and economy, has adequate facilities to accommodate the needs of its citizens.

The concept of polarization between cities and villages can be questioned when globalization and modernity reach remote areas and result in relations without conventional geographical boundaries. Appadurai (1996) said that today is different from the past which is based on a particular place and localistic, due to contemporary high speed of transportation and rapid flow of information, so that relations between peoples are placeless and having flows ( $p$. 29 ), it raises the idea of "global cultural flow." In this concept, globalization has five dimensions, namely ethnoscapes, technoscapes, financescapes, media-scapes, and ideoscapes (p. 33). The concept of the 'scapes' of Appadurai is disjunctive, although related but not causally ordered and not understood as a center-periphery relation model (Heyman \& Campbell, 2009). Therefore, the relationship between Ruteng and the surrounding villages was only analyzed by focusing on technoscape and mediascape among the five dimensions.

Technoscapes, in the form of technology, both high and low, both mechanical and informational (Appadurai, 1996), led to changes in villages in the Manggarai region. Infrastructure development in the form of roads and electricity networks supported by technology products in cellular telephones, radios, and televisions has provided the mobility of residents from villages to cities, both for settlers and commuters who travel daily.

Mediascapes, in the form of television shows, radio, and social media that accessed via satellite discs and smartphones, shortens the delivery of information. It shows a modern lifestyle that is different from the agrarian lifestyle in villages of the region. Furthermore, mediascapes in Appadurai's view,

Provide [...] large and complex repertoires of images, narratives, and ethnoscapes to viewers throughout the world, ... [so] The lines between the realistic and the fictional landscapes they see are blurred, so that the farther away these audiences are from the direct experiences of metropolitan life, the more likely they are to construct imagined worlds that are chimerical, aesthetic, even fantastic objects, particularly if assessed by the criteria of some other perspective, some other imagined world." (p. 35).

Television broadcast content gives rise to an imagined world of residents in the village about life elsewhere that is different. It encourages them to travel outside the region to objectify their ideas. The vehicle 
of information, according to Brown's study in Costa Rica cited by Papastergiadis (2000), has an essential influence on increasing the possibility of mobility. Brown proposed the concept of migration chain where prospective migrants obtain information from relatives who have settled in the city about the differences in the conditions of their area with their destination so that he follows in the footsteps of relatives, friends, and relatives. The effect of the migration chain has an essential role in encouraging residents of a village to mobility to the city because it shows the strength of informal communication mechanisms and the role of family, friends, or relatives in new places to facilitate the adaptation of migrants. This Brown's concept can be used as a reference to see the role of friends and relatives as a motivator for villagers in Manggarai to go and do activities in the Ruteng area.

\section{Agriculture as a Major Sector in Manggarai}

Geographically, Manggarai is on the western tip of Flores Island, and part of its territory is hilly. This condition causes variations in altitude in various regions ranging from 0-1000 $\mathrm{m}$ above sea level (BPS Manggarai Regency, 2014). Hilly areas dominate the area of Manggarai, causing the majority of the region to have cold air with average temperatures in the daytime between $20^{\circ}-28^{\circ} \mathrm{C}$ and nighttime between $12^{\circ}-18^{\circ} \mathrm{C}$ (Hemo, 1988). The natural conditions that make most of Manggarai residents depend on agriculture and plantations. Coffee, candlenut, and cloves become products of smallholder plantations, while vegetables, rice, and crops become commodities traded in the local market to meet the needs of the local population. In addition to farming, the majority of residents raise livestock in the form of buffalo, horses, cows, pigs, and chickens. Pigs are the dominant animals to be farmed because besides being consumed, the meat also has a particular function in traditional events, while goats and cows sell outside the island.

Based on data from BPS Manggarai Regency, planting area in the area in 2014 was 22,149 hectares and concentrated in Satarmese, West Satarmese, and Ruteng Districts (BPS Manggarai Regency, 2013). Agricultural workers in the same year totaled 89,381 people, with the majority being female, namely 50,036 people. This agricultural business in the following year experienced a decline in labor to 81,828 , with 44,624 women workers even though agricultural land increased to 26,034 hectares (BPS Manggarai Regency, 2014). This increase in land area is possible because of the use of idle land into productive land and the existence of agricultural mechanization. Based on this data, it appears that agriculture is still a mainstay for most Manggarai residents.

The reduced number of workers in the agricultural sector shows that although the sector remains a mainstay, the population is looking for other employment alternatives to make ends meet. The cause of the change in orientation from agrarian to other fields is caused by two factors, namely the agricultural sector itself and the non-agricultural sector. The leading cause of the agricultural sector is the high cost of agricultural production facilities such as fertilizers and medicines. The high price of agricultural production facilities makes farmers need significant capital to work on their land. The second factor is the high daily wages in rural areas due to reduced population and labor shortages. The wages of agricultural land laborers increase from year to year so that landowners must spend more and more funds to work on the land. The third factor is seasonal changes so that the yields cannot be predicted. Failure to harvest or change the traditional planting cycle due to erratic 
rainfall reduced the results of the farmers' business.

Non-agricultural factors that cause people to switch to other businesses are high levels of education and increased nonagricultural skills owned by residents. More and more educational facilities in rural areas make young people have a higher level of education than their parents. This highly educated group hopes to find work outside the service sector agriculture, such as becoming private employees or civil servants (Civil Servants). Second, residents gain skills through a variety of training and courses that are facilitated by the government and privately. The various training alumni chose to become entrepreneurs according to their new skills. In addition to the two factors, the influence of information technology entering rural areas cannot be ignored. Various media that can be accessed directly by the public, such as radio and television as well as communication facilities such as mobile phones with various features, bring discourse about the field of work or other areas for a living.

\section{Mobility of Population from the Village to the City in Manggarai}

The mobility of residents from villages in Manggarai to various cities in Flores and outside the island caused by economic and social reasons relating to the agricultural sector and outside of that field (Yuliantari, 2016a). Reasons from economic standpoint include: first, living in a city makes it easy to get cash through trade and services, that different from the exchange system in the village, which is still closely influenced by the barter system. Tina who work in the bakery shop explained,

"Kalau di kota kami dapat gaji bulan[an], sehingga tidak repot kalau butuh uang mendadak dari kampung (We get a monthly salary in the city, so we don't have difficulty when people in the village suddenly need money)"

Beth, Tina's friend, supported her argument,

"Kalau tunggu panen, hasilnya tidak tentu, apalagi kalau sudah ada raung (If we wait for the harvest, we cannot be sure of the yield, especially if we already have debt)"

In Manggarai rural communities, the barter system does not only apply between goods and goods but also goods and services. With this system, the exchange rates that apply are following the agreements between individuals who make exchanges. The more valuable the goods or services exchanged, the more exchange rates for exchange commodities. The period of payment also affects the exchange, the longer the payment period, the more goods or services as a means of payment. This barter system is quite complicated, requires time to implement, and is not as flexible as a currency, so payment with money is preferred because it is secure and scalable.

Second, the livelihoods as traders and laborers provide more certainty of income compared to work as traditional farmers. In the traditional farming systems, the yields depend on the season and weather conditions. Changes in natural conditions cause the possibility of crop failure to become even higher so that farmers' income from season to season cannot be predicted. John, a vegetable trader from Nanu, a small village in Rahong Utara district, explained about the uncertain condition,

Cuaca ini tidak menentu; padi atau kopi tidak ada hasil macam dulu. Makanya kami tidak bisa bergantung di situ (The climate is changed; the results of rice or coffee beans are not as good as before. That is why we cannot depend on it as we used to)" 
Besides, the fluctuations in agricultural prices determined by intermediary traders cause the harvest is not always profitable for farmers, they often suffer losses because the income is smaller than the cost incurred. Markus, a gasoline seller, stressed that working as a laborer or trader in a city is considered to be able to minimize that risk,

"Saya ada kebun kemiri, tapi harga kemiri per kilo murah sekali, mana untuk biaya kerjanya, mana untuk angkutan ke kota, hasilnya tidak sesuai. Lebih untung jual bensin atau kerja di toko (I have a candlenut farm, but the candlenut price is meager, the cost of processing and transporting it to the city is more than the selling price. It's better to sell gasoline or work in a shop)"

Salaries obtained by workers have standardized, and trading is considered more accessible, because they do not require labor costs, and have a lower risk of failure than agriculture.

Third, the majority of migrants who work as peddlers or laborers intend to raise the capital to work on rice fields, coffee, and candlenut farm in the village. They send money to family members or relatives in the village as capital to work on their fields or farms. After harvesting, coffee, candlenut, cocoa, and vegetables can be sold to the city, while rice is used to meet family needs or is traded between villages. Densi, who always keeps her money from working in a vehicle spare-parts shop for her family, said,

"Kami kirim uang ke desa untuk kerja kebun atau sawah, beli pupuk dan obat-obatan [...] agar hasilnya dapat dijual ke kota (We send money to families in our villages to manage our farms or rice fields, such as buying fertilizers and pesticides, [...] so that the harvest can be sold to the city)"
Besides, three other informants said that sending money to their family also helped them to overcome losses in crop failure,

"Kalau hasil [panen] tidak bagus, masih ada modal untuk musim tanam berikutnya (In case of crop failure, we still have the capital for the next planting season)"

In addition to economic factors, there are also socio-cultural factors caused by the influence of mediascape. The nature of information obtained from television and radio broadcasts, film and smartphone "[...] tend to be image-centered, narrativebased accounts of strips of reality, [...] and can be formed of imagined lives, their own as well as those of others living in other places (Appadurai, 1996, p. 35). It raises new awareness and assumptions about the place of origin. First, the view of conditions in rural areas are less favorable in terms of public facilities and infrastructure as well as poor citizens' knowledge. It is supported by the fact that there are uneven facilities and services for the community, such as health centers, terminals, roads, electricity, and the availability of clean water. While some cities that are developing in the Manggarai Raya region (Regus \& Deki, 2011), such as Ruteng in Manggarai, Labuan Bajo in West Manggarai, and Borong in East Manggarai provide more employment opportunities, adequate facilities, service facilities to the community affordable, and modern lifestyle. This reality drives rural people to do mobility. Ria, one of the spare-part vehicles shop's employee, explained,

"Di kota segala macam ada, kalau butuh sesuatu tidak setengah mati carinya (Everything is available in the city if we need something it's easy to get it)" 
Second, the effect of mediascape is also seen in the migration chain due to communication with residents who have migrated (Samers, 2010; Tacoli, McGranahan, \& Saterthwaite, 2015), people who live in villages are encouraged to follow friends or family who has lived outside their area. Tina explained of her relation to Beth, who worked in the same place.

"Saya pergi ke Ruteng karena dapat info kerja dari dia melalui hape, [...] Jadi ada tempat tujuan (I went to Ruteng because I got information about job vacancies from her through hand phones [...] So I have a place to go)"

According to Brown in Papastergiadis (2000), the effects of migration chains are higher than migration based on individual desires. Information obtained from friends, relatives, or family is more convincing and trusted because the informer always provides temporary shelter and facilities needed if friends or relatives come to his area. This action in the context of Manggarai kinship is not only a form of primordial solidarity but is a tribute to family relations in his hometown (Yuliantari, 2016a). This migration chain is facilitated by road infrastructure. However, the number is still limited, which encourages the operation of transportation facilities such as bemo (rural transportation in the form of small cars) and colt (trucks) to serve trips between villages and cities and market agricultural products or trade-in essential goods for residents in various remote areas.

Third, there is the desire of young people to look for life experiences that are different from their home regions. Their goal is to get cash to meet the necessities of life, enjoy entertainment facilities, and experience the modernity in the city. The reluctance to work in the agricultural sector is caused by working on the farm more time-consuming and requires much energy compared to working as a laborer in the city.
Besides mediascape, technoscape also influences the villagers' decision to go to the city. The influence of technoscape in the form of information and transportation technology, first, encourages parents to try to get their children to have a better education. Although limited, Ruteng provides a means for quality early childhood education to tertiary education. Schools managed by the Catholic mission and the general public are known to be highly disciplined and have excellent facilities compared to schools in the countryside. These schools are targeted by parents who want to send their children to studies outside the island or regions.

Second, the mountainous topography of Manggarai, for decades, has been a barrier to the mobility of residents from villages to other villages or cities. The existence of infrastructure in the form of roads facilitates mobility, shortens time, and reduces travel costs. These factors, coupled with the influence of information technology, have caused most villagers to move to cities to find work or become small traders.

Outside the economic and socio-cultural context, some people have moved to the city because of conflicts with fellow villagers. Usually, the conflict is large enough so that the adat (traditional custom) mechanism imposes severe sanctions on the individual. Mobility outside the area of origin is an effort so that the conflict does not occur for long or cause casualties. Cities as new dwellings are more suitable because of their heterogeneous population so that social sanctions against conflicting individuals can be eliminated.

Based on the description above, in general, there are two types of businesses carried out by villagers who move to cities, namely trading and selling services. In the trade sector, they sell daily necessities such as vegetables, fruits, cakes, betel nut, fish, and fuel (Yuliantari, 2016b; Yuliantari, Adi, \& Ganap, 2015). They sell their merchandise permanently in the market or peddle around. 
These traders go to the city to develop the capital they already have. The capital is in the form of money invested in the trade sector, land management, and the purchase of agricultural products from the village such as coffee, cloves, vanilla, candlenut, and chocolate.

The majority of rural residents engaged in services work as domestic helpers. In addition to that, they work as an assistant of a driver, drivers, motorcycle taxi drivers, shop employees, laborers in several home industries, construction workers, and laborers in the market. Prospective employers usually get references for migrants from friends or relatives in their village. Based on that reference, prospective employers can determine their salary and type of work.

\section{Ruteng as the center of}

\section{Manggarai and Its Relationship With The Surrounding Villages}

Administratively, Ruteng, the capital of the Manggarai Regency, is in Langke Rembong District. This sub-district consists of 11 villages with an area of $60.54 \mathrm{Km}^{2}$. Based on the 2013 census, the population was 71,534 people with a density of $1,181.59$ People/Km (BPS Manggarai Regency, 2014a). With only 1200 hectares of agricultural land, the majority of Ruteng residents work in the non-agricultural sector, such as Civil Servants, private employees, workers in small industries, as well as workers in the domestic sector.

As a district with a relatively narrow area, Langke Rembong District has a significant urbanization rate. Based on BPS records in Manggarai Regency, there were 2,045 newcomers in 2009 (BPS in Manggarai Regency, 2009). Although there is no data on the origins of migrants, the small number of people outside the area in the Manggarai Regency supports the assumption that most of the migrants in the Langke Rembong subdistrict are from villages in the Manggarai area. This assumption is supported by data on the decline in the labor force in agriculture between $2011-2013$ from $34.48 \%$ to $33.36 \%$, while the service and trade sectors increased from $30.23 \%$ to $30.46 \%$ (BPS Manggarai Regency, 2014b). An increase in the service sector workforce compared to agriculture shows that a portion of the population has shifted from rural farming to service workers in the city.

As the center of government and economic, Ruteng is an ideal place for residents of the surrounding villages to find work. A large number of population, the diversity of professions, limited land, and the amount of income open business opportunities and job vacancies for migrants. Ruteng residents from various Manggarai areas and the surrounding districts mostly work outside agriculture. This opportunity was used by residents from villages around Ruteng to market agricultural products and fuel. Also, migrants who come from outside Manggarai, Chinese people, and some Manggarai people who become private employees or government employees, need employees or domestic workers to facilitate business or domestic work. This opportunity is used by residents from rural areas, especially young children, to become factory workers, shop employees, and household assistants. Of the three home-based bread factories and one bottled water factory in Ruteng, most of the employees come from outside the area.

In addition to the ease of obtaining employment, the selection of Ruteng by most residents of the Manggarai area, compared to mobility to other places, is a cultural similarity. The condition of urban areas in Manggarai is not too different from the surrounding areas. This cultural similarity makes it easier for someone to make adjustments to the surrounding 
environment. According to Karst (1986), there are two choices for migrants going to other cities or countries to form solidarity with their group called "inward turn" and to assimilate the community at their destination known as "outward turn." In one part of this concept, it is said that the higher the number of communities coming from an area, the migrants tend to join their groups. Collier's opinion quoted by Prinz (2019) said that the more groups of people living in a place, the more likely the newcomers to join the group compared to the desire to assimilate the local population.

In the context of Manggarai, this "inward turn" provides benefits to job seekers because this cultural similarity also causes employers to understand the habits of their employees, especially certain months where employees or household assistants need permission to return to their place of origin. For employers of the same ethnicity or ethnicity, cultural similarity means the similarity of cultural codes, so that understanding reduces conflicts that may occur and disrupts the relationship between the two.

Even though the obstacles encountered in the interaction between the Ruteng people as consumers and employers with the surrounding villagers as producers and employees are relatively small, social conflicts are still encountered between the two. The conflict included: the large number of villagers who moved to Ruteng caused an increase in labor supply. A large number of workers causes low labor costs. Most workers in the private sector do not get paid according to regional minimum requirements because of the number of wages determined by the type of work and the length of service of a person. Wages can also vary depending on each employer, although among employers, there are minimum standards based on prevailing customs.

The effects of the migration chain and cultural similarity between workers, on the one hand, make it easier for employers to get workers. They hire laborers based on recommendations from workers who had already worked there. Ms. Rini, a spare-part vehicles shop's owner, explained how to get employees,

\begin{abstract}
"Saya dapat pegawai baru dari temannya yang sudah kerja di sini. Mereka satu desa, jadi saat pulang ke kampung mereka ajak teman untuk kerja di sini (I got a new employee from my workers who have worked here first. They are from the same village, so when my worker returned to her village, she urged her friends to work here)"
\end{abstract}

The advantage of recruiting employees from the same village is that the safety and comfort of the workers are guaranteed because of shared habits, a sense of solidarity and commonality. This conducive atmosphere can increase the effectiveness and efficiency at work.

On the other hand, the risk of employing workers from the same region is that industrial work patterns cannot be fully implemented (Yuliantari, 2016b). Ms. Hila of the bakery shops mentioned the problem as follows,

"Sulitnya pekerja yang berasal dari satu desa itu, kalau satu dikeluarkan atau minta keluar, lainnya ikut berhenti. Padahal mungkin kita keluarkan satu orang yang tidak baik kerjanya, tapi teman yang tidak bermasalah ikut keluar (It's hard to have workers from the same village, if one is expelled or resigns, the other follows. Even though we might fire one person who is not working well, her friends who have no problems also resign)"

Resignation by a friend or relative is a form of solidarity, especially if the resigned has a significant influence on them. Likewise, if one of the workers submits a permit to attend a custom event in his village, a friend or relative in the area asks for permission 
to attend a similar event. Traditional events that often make workers return to their villages are penti (Manggaraian New Year tradition), wagal (marriage ceremony), wuat $w a^{\prime} i$ (farewell ceremony for family members who will go overseas), and kenduri (memorial service for deceased family members).

Also, there are differences in perspectives on work patterns and rhythms between industrial and rural agrarian communities. In rural areas, the work system is more flexible. Work can begin between eight and nine in the morning and is followed by a ritual of resting for coffee at eleven o'clock in the morning, lunch at one o'clock, an afternoon break for coffee at three o'clock, and work ends at five in the evening. Industrial societies have a different work system that is working for eight hours a day, starting at eight in the morning until four in the afternoon with an hour's rest. This difference in habit leads to the assumption that rural workers are lazy and cannot work according to the demands of the employer.

The second conflict that occurred was the attachment of workers to the customs in his or her village. The strong relationship between the individual and the community causes them to put the interests of the aboriginal community more than the commitment to work. Ms. Rini complained about the attitude of workers who are considered not serious because they resigned only after two weeks of work,

"Dia minta pulang ke kampung, kemarin kakaknya datang ke sini, kakaknya bilang dia disuruh pulang untuk bantu jaga anak [...] saya jadi repot cari gantinya karena dia tidak serius kerja (She insisted to go back to the village, [because] his brother came here yesterday, he said that she had to go home to help look after his children [...] I was having a hard time finding a replacement because she was not serious about working)."
Workers feel that their presence in their family or community is more important than work; if they are needed at their place of origin, they can easily give up their jobs and return to the village.

The arrival of villagers to Ruteng, apart from bringing influence on the city's community, take effect on their place of origin. Positive things can be seen from the significant cash flow brought by the nomads. The massive flow of money is encouraging economic development in the village of origin of migrants and the surrounding area. The families of the workers use the funds brought as capital to cultivate farms and rice fields, trade, livestock, and transportation. The development of these various businesses open new jobs, absorb labor in the region, to improve the welfare of the community.

Another positive thing is that the knowledge gained through education or interaction with people outside of its culture contributes to advancing life and broadening the horizons of thinking. Knowledge of technology helps rural communities, which still use traditional techniques to process commodities that are the products of their regions so that they have more value than the production of raw goods. Migrants can also change the mindset of villagers who embrace traditional concepts in the fields of health and education. With the presence of community members from overseas, they gain knowledge about self-care and health improvement through food and the use of medical facilities that have been provided by the government. In the field of education, the success of migrants outside the region encouraged villagers to increase their children's knowledge through schools in their area and send learning to the cities. This increased knowledge encourages tolerance and openness to new values that bring progress.

On the other hand, conflict can occur if the customs of the city contradict with 
local traditions. One example is the habit of socializing through door-to-door visits. Social interaction in cities is not always in the form of physical presence. Systems and work patterns in industrial areas limit the encounter directly with virtual communication. Busyness and limited working hours require them to rely on technological tools to establish relationships or stay connected with their extended families, in contrast to agrarian societies that are concerned with physical encounters. In the local context, a physical encounter is needed because it is more humane than the relationship through the means of communication or other intermediaries. In other words, habits in industrial societies that differ from the concept of socializing in an agrarian society can cause social problems. The close kinship between members of the village community requires that migrants returning to their home regions must return to local customs. Deviant behavior from customs in the environment is considered inappropriate or violates customs.

\section{Conclusion}

Technoscape and mediascape are pulling factors for urbanization in Ruteng. Technoscape in the form of physical infrastructure development in rural areas that support progress in other fields are electricity networks, digital technology, satellite dishes, and roads. The influence of technology on easy access to information and travel from villages to cities facilitates direct and indirect interaction between residents of cities and villages.

Furthermore, mediascape, in the form of television shows, radio, and social media that is accessed via satellite discs and smartphones, shortens the delivery of information and shows a modern lifestyle that is different from the agrarian lifestyle in villages in the Manggarai region. The ease of access to transportation and information, the desire to follow modern lifestyles, and the easiness of getting wages from the service sector caused people in the surrounding villages to move to Ruteng.

The local view supports this condition as a push factor. The Manggarai people have a go' et (traditional expression) that is "lalong bakok du lako, lalong rombeng du kole" (whitefeathered chickens when leaving, coloredfeathered chickens when returning) means success in a foreign land brings honor and pride at the place of origin. Based on this view, Manggarai people are encouraged to go elsewhere to gain insight and achieve success. A "wuat $w a$ ' $i$," the event made for people who want to migrate outside their villages, support this hope.

Undeniably, the presence of villagers to Ruteng brings benefits for the townspeople because it can meet the needs of the workforce. Cultural and linguistic similarities make the interaction between city residents and villages easier, but their presence also caused conflict due to differences in perceptions and habits prevailing in the two regions.

\section{Declaration of Ownership}

This article is our original work.

\section{Conflict of Interest}

There is no conflict of interest to declare in this article.

\section{Ethical Clearance}

This study was approved by the institution.

\section{References}

Appadurai, A. (1996). Modernity at large: Cultural dimensions of globalization. University of Minnesota Press. 
BPS Kabupaten Manggarai. (2009). Manggarai dalam angka. Pemerintah Daerah Manggarai.

BPS Kabupaten Manggarai. (2013). Manggarai dalam angka. Pemerintah Daerah Kabpaten Manggarai.

BPS Kabupaten Manggarai. (2014a). Manggarai dalam angka 2014. Pemerintah Kabupaten Manggarai.

BPS Kabupaten Manggarai. (2014b). Indikator kesejahteraan rakyat Kabupaten Manggarai 2014. Pemerintah Daerah Kabupaten Manggarai.

Creswell, J. W. (2016). Research design: Pendekatan metode kualitatif, kuantitatif dan campuran. Pustaka Pelajar.

Dana, J., Dawesy, R., \& Peterson, N. (2013). Belief in the unstructured interview: The persistence of an illusion. Judgment and Decision Making, 8(5), 512-520.

Hagul, A., \& Lana, C. D. (1989). Manggarai kemarin, hari Ini, dan esok. Dinas Pendidikan dan Kebudayaan Manggarai.

Hemo, D. (1988). Sejarah daerah Manggarai NTT. Tanpa Penerbit.

Heyman, J. M., \& Campbell, H. (2009). The anthropology of global flows: A critical reading of Appadurai's 'disjuncture and difference in the global cultural economy'. Antropological Theory, 9(2),131-148.https:// doi.org/10.1177/1463499609105474

Janggur, P. (2010). Butir-butir adat Manggarai II. Yayasan Siri Bongkok.

Karst, K. L. (1986). Paths to belonging: The constitution and cultural identity. North Carolina Law Review, 2(4), 303-377.

Papastergiadis, N. (2000). The turbulence of migration: Globalization, deterritorialization and hybridity. Polity Press.
Prinz, A. (2019). Migration, cultural identity and diasporas an identity economic approach. IZA Journal of Development and Migration, 10(1), 1-20. https:/doi. org/10.2478/izajodm-2019-0001

Regus, M., \& Deki, K. T. (2011). Gereja menyapa Manggarai. Parrhesia Institute.

Samers, M. (2010). Migration. Routledge.

Stead, D. (2002). Urban-rural relationships in the west of England. Built Environment, 28(4), 299-310.

Stewart Jr, C. T. (1958). The urban-rural dichotomy: Concepts and uses. American Journal of Sociology, 64(2), 152-158.

Tacoli, C., McGranahan, G., \& Saterthwaite, D. (2015). Urbanization, rural-urban migration and urban poverty. International Organization for Migration (IOM).

Webb, R. P. (1994). The children of Mori Kereng: Education dan strategies in Manggarai Flores. Philippine Quarterly of Culture and Society, 22(2), 141-158.

Willemsen, M. (1998). In memoriam Jilis A.J. Verheijen SVD 26 March 1908 - 25 April 1997: A collector's life. Bijdragen tot de Taal-, Land-en Volkenkunde, 154(1), 1-12.

Woods, M. (2011). Rural. Routledge.

Yuliantari, A. P. (2016a). Contestation between global and local in Manggarai rap music. Rubikon, 3(1), 1-9.

Yuliantari, A. P. (2016b). "Molas baju wara": Hybridity in Manggarai rap music. CELT Journal, 16(2), 201-216. https://doi. org/10.24167/celt.v16i2.769

Yuliantari, A. P., Adi, I. R., \& Ganap, V. (2015). Ruteng is da city: Representasi lokalitas dalam musik rap Manggarai. Resital, 16(2), 65-74. https://doi.org/10.24821/ resital.v16i2.1511 
Ans Prawati Yuliantari 